\title{
Scientific Vocation in Danger: The University Professor in the Global Era
}

\author{
Javier S. Castresana \\ University of Navarra, Pamplona, Spain \\ Email: jscastresana@unav.es
}

How to cite this paper: Castresana, J. S. (2020). Scientific Vocation in Danger: The University Professor in the Global Era. Open Journal of Philosophy, 10, 539-554. https://doi.org/10.4236/ojpp.2020.104038

Received: September 5, 2020

Accepted: November 27, 2020

Published: November 30, 2020

Copyright $\odot 2020$ by author(s) and Scientific Research Publishing Inc. This work is licensed under the Creative Commons Attribution International License (CC BY 4.0).

http://creativecommons.org/licenses/by/4.0/ (c) () Open Access

\begin{abstract}
Being a professor at university demands thinking about vocation along life. And not only about ones' vocation but also about others'. Vocation for teaching, vocation for learning, vocation for science... Vocation is so important that merits a philosophical approach. Following one's own vocation is perhaps the most important task everyone has to do in one's own life. Following the dictates of personal vocation is without a doubt guarantor of a full, authentic life. And, on the contrary, not following the personal vocation can be one of the reasons for living a life without meaning. Personal vocation as a task, according to Julián Marías' philosophy, is introduced in this work, together with the concept of enthusiasm immersed into the vocational pathway. Vocation among university professors seems to be in danger in the global world. Possible causes for it are analyzed.
\end{abstract}

\section{Keywords}

Vocation, Profession, Human Person, Self, Circumstance, Chance, Freedom, Trajectories in Life

\section{Introduction}

There are more and more vocational scientists who, working at universities where they have to combine teaching and research at a high level, are suffering a loss of strength to dedicate themselves to research. Why is this happening? Simply because there is a lot of work to do? Or are there other causes? If these scientists are vocational for research, why does scientific activity itself suffer more than teaching after years of dedication to both? Certainly research has a higher level of complexity, but these scientists are vocational for research.

After more than 30 years of professional experience at research institutions and universities in different countries, I believe that what is possibly happening 
in some of those scientists who combine their work with teaching is a loss of enthusiasm for research. I propose below, a philosophical analysis, following Julián Marías' arguments (1990) on what the vocation is, as well as one of the elements associated to it: enthusiasm. Perhaps that will help us to figure out why some university professors seem to lose their vocation to experimental science along their careers-and if they truly do.

The manuscript is organized as follows: first, it starts by a definition of the Spanish word ilusión as enthusiasm in life, in order to have in hands a possible translation of ilusión into English, as this word has a positive and a negative meaning in Spanish, while its positive meaning is indeed lacking in other languages. Ilusión has been philosophically studied by Julián Marías. We include enthusiasm as a possible translation of ilusión for our analysis of its impact on personal vocation in our work. The whole manuscript is a reflection on how enthusiasm is related to one's personal vocation.

Secondly, an analysis of the distinction between the self and the personal circumstance is presented. Chance, necessity, freedom and destination are further discussed in order to show that not only the personally chosen project of life has to be taken into account by oneself, but also the reality around (the circumstance) has to be a part of the project to be lived. I explore, in light of Marías' philosophy, the categories of the circumstance: it is there, around oneself, by chance, although it is necessary to be matched, joined, to the personal self. But personal freedom can decide whether or not to admit the circumstance by oneself. If properly freely assumed, although appearing by chance, and being necessary, the destination of oneself to another-self will be produced with time, should the person admits his/her personal circumstance.

Thirdly, generic and partial (concrete) vocations are defined later on. It is important to realize that only personal vocations correspond to partial vocations. These are the ones in which each one person consists. But if the vocation is not answered, the self will not grow, even when it has felt the vocational call. Freedom is essential to fulfill the concrete vocation and to admit the circumstance into it.

Then, I explored why there are some professionals that do not really feel enthusiastic about their work, in spite that they develop jobs that are considered highly vocational. Several causes to explain it are presented, all inducing a work done with a lack of enthusiasm. The professional task has not been personalized and the professional product is of low value, the same as the professional's selfgrowth.

Later, Marías disserts about the trajectories or vocational paths along life, to show us that even being enormous the number of pathways to possibly be followed, one has to discover his/her own trajectories in his/her own personal life. Some pathways might be discovered to be ready for a specific person from the beginning of life. Some other ones appear in front of oneself later in life, even in the elderly, as new non-explored trajectories. Marías, then, speaks about the hierarchy of trajectories. 
Next, I describe Marías' link between enthusiasm and authenticity. He believes that the degree of authenticity of the various trajectories, is the element of enthusiasm that accompanies them or that is lacking in them. He even presents the balance of our enthusiasm to show who is really each one of us. Then, we could better understand each person and ourselves, as personal enthusiasm presupposes authenticity of vocational answers. Inauthenticity, on the contrary, freely consented by the subject, would be associated with lack of enthusiasm.

The last part of the chapter is dedicated to confronting enthusiasm and the academic vocation of university professors, pointing out the main problems that might make university professors lose enthusiasm, and consequently, lose their vocation. The manuscript may have the limitation of just having studied one specific book by Julián Marías (Breve tratado de la ilusión), although this is the only book that he dedicated to the ilusión (enthusiasm). Nevertheless, no more authors have been discussed on this topic in this work, although as Marías says, the concept of ilusión has been even untouched along the history of philosophy.

\section{Ilusión and Vocation in Julián Marías' Philosophical Anthropology}

\subsection{Ilusión-Enthusiasm in Life: The Concept}

Before entering into the vocation, it is convenient to define an important concept that, as we will see, is associated with it: the concept called ilusión in Spanish.

Julián Marías (1914-2005), a Spanish philosopher, disciple of Ortega y Gasset (1883-1955) talks about the ilusión (word in Spanish) (Marías, 1990) as a philosophical concept not sufficiently studied throughout the history of philosophy. This word in Spanish can have a negative or positive meaning. The latter is even more frequently used. While the English this voice lacks the positive meaning.

The word ilusión in Spanish (Diccionario de la Lengua Española, 2019), may be used with a negative meaning (concept, image or representation without true reality, suggested by the imagination or caused by deception of the senses), or with a positive meaning (hope whose fulfillment seems especially attractive). As said by Marías, Spanish is the only language ascribing a positive meaning to ilusión.

On the other hand, the word illusion, the direct translation of ilusión from Spanish to English has only a negative meaning (Cambridge Dictionary, 2020), an idea or belief that is not true (as in: My boss is laboring under the illusion that (= wrongly believes that) the project will be completed on time). A second meaning corresponds to something that is not really what it seems to be (as in: The impression of calm in the office is just an illusion).

Philosophically Julián Marías has studied the concept of ilusión. He has even published a book: Breve Tratado de la Ilusión (Short Treatise on Enthusiasm) (Marías, 1990). We need a word in English that gives a positive meaning, the closest meaning to the word ilusión in Spanish. I propose here the English word 
enthusiasm. Illusion will not definitely be a good choice in English, given its unique negative meaning, not useful for our purpose of enhancing the value of ilusión in personal life.

In his short book Breve Tratado de la Ilusión (Short Treatise on Enthusiasm), Marías (1990) develops an 11-page chapter on enthusiasm and vocation. It may be interesting in our study to scrutinize this brief chapter of his small book, since it contains part of Marías' thought on vocation, a concept that is not developed in any specific book of his. Marías begins this chapter with a definition of the term vocation, linked to the concept of personal dedication to religious life, or to a job, career or profession. It is the concept of partial or schematic vocation, suitable for all, common to many, therefore generic.

En todos los casos, y aún en la tardía ampliación profana, se entiende por vocación algo genérico, esquemático. Vocación religiosa, o de médico, abogado, militar, escritor, explorador, pescador, lo que se quiera. Son siempre cauces con una significación profesional o muy próxima a ella (Marías, 1990: p. 67). [Translated: In all cases, and even in the late secular expansion, vocation is understood as something generic, schematic. Religious vocation, or medical, lawyer, military, writer, explorer, fisherman vocation; whatever you want. They are always channels with a professional significance or very close to it].

Partial vocations are secondary forms of the vocation for Marías, in the sense that they are not strictly personal, singular or unique vocations, but are common to many people, reason why Marías defines them as generic.

A esto llamo vocaciones parciales, que afectan a aspectos, facetas o porciones de la personalidad; que por eso pueden ser comunes a muchos, y por consiguiente tienen un carácter genérico. Sea cualquiera su contenido, y por excelso que pueda imaginarse, son formas secundarias de la vocación, en la medida en que no envuelven a la persona en su totalidad y no tienen carácter singular, único (Marías, 1990: p. 67). [Translated: I call this partial vocations, which affect aspects, facets, or portions of the personality; that is why they can be common to many, and therefore have a generic character. Whatever their content, and however sublime it may be imagined, they are secondary forms of vocation, insofar as they do not involve the person in its entirety and do not have a singular, unique character].

\subsection{The Self and the Personal Circumstance}

Starting to deal with the subject of vocation in its most personal and unique sense, Marías compares the approach he made regarding this subject in two of his previous books: Introduction to Philosophy (1947) and Metaphysical Anthropology (1970). In the first of these, the vocation is shown to the person within the social context in which the person realizes himself/herself. Marías admits that a host of possibilities is presented to the person, socially and historically, the person feeling forced to freely choose what would constitute their unique personal vocation.

La cuestión de la vocación aparece en el contexto de las posibilidades que el 
hombre encuentra en su contorno social: Por ser ya social e histórico, encuentro en mi circunstancia o mundo posibilidades de ser hombre, esquemas genéricos, figuras de vida que no he inventado yo, aunque siempre las ha inventado originariamente un hombre individual, y en todo caso, para que esas posibilidades recibidas puedan ser mías, para que puedan ser las de mi vida, necesito hacer algo: concretamente, elegir entre ellas, decidir cual voy a adoptar entre las que me son presentadas por el contorno; y esto, a su vez, por un esquema de mi vida, más vago y general, del cual soy irrenunciable autor, y que se llama, con un nombre cargado de resonancias y del que tendremos que hablar más adelante, vocación (Marías, 1990: p. 68). [Translated: The question of vocation appears in the context of the possibilities that man finds in his social surroundings: Being social and historical, I find in my circumstance or world possibilities of being a man, generic schemes, figures of life that I have not invented although they have always been originally invented by an individual man; and in any case, so that those possibilities received can be mine, so that they can be my life's, I need to do something: specifically, choose between them, decide which one I am going to adopt among those presented to me by the contour; and this, in turn, by a more vague and general scheme of my life, of which I am an inalienable author, and which is called, with a name full of resonances and of which we will have to speak later, vocation].

The vocational path is personal and historical. Each person must respond to the calls received-by way of voices according to Marías-from a certain figure, that figure that one has freely chosen as a destination or vocation. The self and the personal circumstance are transformed in the vocational task. The self, while the vocation is fulfilled, will develop, will tend to grow, trying to become that other-self that demands constant and concrete actions so that the initial-self transforms and becomes the vocational-self. The personal circumstance is that accumulation of reality that orbits around the personal-self, all that external to the intimate-self, which can help or complicate the vocational path. The circumstance must accept the call and be able to accommodate the transitional-self, the self changing towards the ideal self, throughout life. At the same time, the circumstance changes along the vocational path, since the call-the vocationmakes the self called to become the ideal-self find itself in a new circumstance: that of a self on a vocational journey, always different from a self that has not yet been touched, called, beaten, by the ideal-self before which to surrender inexorably.

Más adelante se habla de lo personal y lo histórico en la vocación; se parte de una figura de vida determinada, que nos da voces y nos provoca a realizarla. La vocación, lo más personal, tiene contextura histórica; y a la vez supone una transformación de la circunstancia para alojar en ella la forma propia y personal de la vocación: Esto explica la esencial conexión y alteración, al mismo tiempo, que la vocación supone respecto de la circunstancia del que se siente llamado (Marías, 1990: p. 68). [Translated: Later we speak about the personal and the historical in the vocation; it starts from a certain figure of life, which gives us 
voices and prompts us to carry it out. Vocation, the most personal thing, has a historical context; and at the same time it supposes a transformation of the circumstance to accommodate in it the proper and personal form of the vocation: This explains the essential connection and alteration, at the same time, that the vocation supposes with respect to the circumstance of the one who feels called].

\subsection{Chance, Necessity, Freedom and Destination}

In the second of his books, Metaphysical Anthropology, which he cites in a Short Treatise on Enthusiasm, Marías presents us with "una aproximación mayor al núcleo irreductible de la vocación total, de la vocación de ser yo" (Marías, 1990: p. 68) ("a greater approximation to the irreducible nucleus of the total vocation, of the vocation of being myself"), through linguistic concepts intertwined around the concept of vocation: chance, necessity, freedom, destination. Thus, it tells us that the combination of chance and necessity, between which we oscillate continuously, has been called destination. Freedom governs the chance-necessity couple. By chance something new appears in my circumstance, a call. And if it is vocational, intimate, entirely personal, I have no choice but to respond positively to it, necessarily. I may not respond; I can say no, but that would be a clearly immoral act; by not accepting that which is exclusively for me; that which is not for anyone else; that which only I can carry out. There is, therefore, freedom of response to the random call, but there are not several unique personal calls, from which I have to choose only one. Vocation is one for one; personal, intimate. And before that call that exclusively I receive, it only remains for me to answer yes; freely, but necessarily. I am necessarily free to respond to my own vocation. Thus, destination is strictly personal only when it is adopted, appropriate, accepted, made mine. We could also define destination as our own vocation, the end of the trend path; the ideal-self that I tend to and that I must become. Thus, freedom governs the chance-necessity relations that the self perceives and the circumstance assumes and welcomes, to try to progress and reach the destination, the ideal-self, the destiny-self. As a consequence of the vocational journey, the attempt to respond favorably to the call, Marías assumes that happiness occurs. Which may be indicative of the opposite as well: the lack of response to the random and personal question to start the vocational path, will surely produce dissatisfaction and vital disappointment.

La entrega libre y necesaria al enamoramiento auténtico es la forma suprema de la aceptación del destino, y eso es precisamente lo que llamamos vocación. Oscilamos, pues, entre el azar y la necesidad; a la combinación de ambas se llama desde hace milenios destino, pero no se ha solido entender bien, porque se lo ha interpretado casi siempre desde una mentalidad de cosas, no como destino personal. $Y$ quien gobierna esa pareja inseparable y enemiga azar-necesidad-que habita en la imaginación-es la libertad. El destino tiene que ser adoptado, aceptado, apropiado, hecho mio; no es objeto de elección, pero tiene que ser elegido; solo así es rigurosamente destino personal o, con otro nombre, vocación. En ri- 
gor, nunca me siento más yo-yo mismo-que frente a un contenido azaroso que irrumpe en mi vida cuando reacciono a él de una manera que brota de la raiz de mi persona; cuando descubro en él el destino que no se elige, y elijo hacerlo mio, serle fiel; con otras palabras, elijo ser yo ese azar inelegible. El destino libremente aceptado, pero no elegido-es decir, elijo que sea mi destino, lo adopto, pero no elijo su contenido-es mi vocación, y la realidad de esta es lo que llamamos felicidad (Marías, 1990: pp. 68-69). [Translated: Free and necessary surrender to authentic falling in love is the supreme form of acceptance of destination, and that is precisely what we call vocation. So we oscillate between chance and necessity; the combination of both has been called destination for millennia, but it has not been well understood, because it has been interpreted almost always from a mentality of things, not as a personal destination. And the one who governs that inseparable and enemy couple of chance-necessity-which lives in the imagination-is freedom. Destination has to be adopted, accepted, appropriated, made mine; it is not an object of choice, but it has to be chosen; only in this way is it strictly personal destination or, with another name, vocation. Strictly speaking, I never feel more myself than facing a random content that bursts into my life when I react to it in a way that sprouts from the root of my person; when I discover in it the destination that is not chosen, and I choose to make it mine, to be faithful to it; in other words, I choose myself to be that ineligible chance. The freely accepted but not chosen destination - that is, I choose it to be my destination, I adopt it, but I do not choose its content-is my vocation, and the reality of this is what we call happiness].

\subsection{Generic and Partial Vocations}

The generic, partial or schematic vocation affects one or another dimension of the person, being therefore more or less abstract. On the contrary, the concrete vocation is unique and exclusively personal. Marías also tells us that such a vocation is that one in which each person consists, and that coincides with one's self. Perhaps we must specify at this point that for a vocation to be something in which one consists, such a vocation must have been developed or, at least, be in the process of realization; if one's self, prompted by the random question, answers yes, it grows towards the ideal-self presented, perhaps still translucent. At the end of the road one will be what one has become thanks to that journey towards the vocational ideal; in this sense, we can say that the concrete vocation is that in which each person consists. But if the vocation is not answered, the self will not grow, even when it has felt the vocational call. Therefore, the free and sustained response over time to the random call or vocation is a necessary condition for the growth of the self. If one does not respond, or stops responding, there is no growth. One consists, therefore, in one's vocation, as long as there is vocational growth. Likewise, the vocation coincides with the self of each person when such growth occurs; if not, there will be a loss of the self, of one's own being, due to the lack of travel through the unique, specific, personal, non-transferable path that is there, waiting for everyone. 
... se ha ido descubriendo que la vocación que he llamado genérica o esquemática no afecta más que a una u otra dimensión de la persona, y es más o menos abstracta. La vocación concreta, en cambio, es única, rigurosamente personal; es la vocación en que cada uno consiste más propiamente, y coincide con el yo de cada cual, entendido programáticamente (Marías, 1990: p. 69). [Translated: ... It has been discovered that the vocation that I have called generic or schematic does not affect more than one or another dimension of the person, and is more or less abstract. The concrete vocation, on the other hand, is unique, rigorously personal; it is the vocation in which each one more properly consists, and coincides with the one's self, programmatically understood].

Finally, it should be pointed out that generic vocations could also become true concrete or individual vocations. One example might be the case of a vocational doctor who puts his/her whole life, his/her whole soul, in the development of what we could call "being a doctor; being this individual and concrete doctor". This doctor would aim to serve his/her patients in the broad sense of the word; not only to cure them, but to be able to attend, listen, put himself/herself at the level of the patients, to serve them in all aspects of their life. There are no illnesses but only sick people; each one of them suffering one or more diseases in a particular circumstance that must also be attended by the doctor, although he/she cannot directly solve it. The non-vocational doctor is likely to only treat the disease and dispatch the patient, as if he/she were a disease. The vocational doctor, on the contrary, will treat the sick particular person; not the disease; making of each patient a new vital and professional experience. That will make the doctor be a special being, a better being, since he/she has developed an apparently generic vocation in a very personal way. $\mathrm{He} / \mathrm{She}$ will be able to say that he/she was born to be a doctor and that he/she has tried to be a doctor in the best possible way, despite the unfavorable circumstances that could have arisen. His/Her patients and the entire society will thank him/her. But who, without a doubt, will receive the greatest benefit will be himself/herself, thanks to following his/her vocational path; that free and necessary path at the same time, which will have perfected his/her own self turning it into the ideal self, in the vocational destination, in the only possible way that the personal self can be perfected: through the free response to the vocation maintained in time, either the concrete-personal vocation or the generic-partial vocation, lived this one in an intimately personal level.

Pero no se olvide que las vocaciones parciales o genéricas, en la medida en que se concretan, se realizan de una manera individual, participan también de ese carácter personal (Marías, 1990: pp. 69-70). [Translated: But do not forget that partial or generic vocations, insofar as they take shape, are carried out in an individual way, they also participate in that personal character].

Enthusiasm, according to Marías, is an ingredient of any concrete vocation (Marías, 1990: pp. 69-70). To the extent that a generic vocation (e.g. a doctor that assumes diseases to be treated and not individual persons to serve) becomes a specific vocation (a doctor that treats individual patients and not just diseases), 
there can be a high degree of enthusiasm at work. There are even examples not linked to what has usually been understood by vocational work; thus, being a farmer or being a housewife can be carried out according to a personal, concrete (not generic) vocation, when the farmer is a farmer of his/her land, and the housewife is a housewife of her family. This possessive sense of the task personalizes the vocational character of the task and enables the development of one's self in any type of work, depending exclusively on whether the person freely chooses to carry out that work in a personal, individual manner.

Cuando la vocación se hace concreta, aunque originariamente sea genérica y nazca del encuentro de ella en la sociedad, realizada en otros, se liga a la propia personalidad, se entrelaza con la trayectoria vital y se convierte en una dimensión de ella. Ya no se trata de la vocación esquemática de médico, sino de este médico individual, definido por una situación no intercambiable y un proyecto personal que transforma la vocación genérica (Marías, 1990: pp. 70-71). [Translated: When the vocation becomes concrete-although being originally generic and born from the encounter of it in society, realized in others-, it is linked to one's personality, intertwines with the life trajectory and becomes a dimension of it. It is no longer about the schematic vocation of a doctor, but about this individual doctor, defined by a non-interchangeable situation and a personal project that transforms the generic vocation].

\subsection{Enthusiasm and Personal Work}

Why are there some professionals that do not really feel enthusiastic about their work, in spite that they develop jobs that are considered highly vocational? We could put the example of teachers, university professors, scientific researchers, lawyers and other professionals always considered vocational par excellence. Not everyone enjoys their vocation; not everyone lives excited in their daily work. In some of them we even know about the exhaustion (burnt-out syndrome) and depression caused by the profession itself. Why does such a thing happen if there is a vocation? Marías refers to several causes, without going into great detail: for example, work done impersonally, without putting the stamp of one's own style on it, could favor disappointment. Perhaps this cause is of an intrinsic order, originated by the person himself/herself, who has not just personalized his/her vocation, being it generic or concrete.

Secondly, if the result of the work is more important than the actual performance of the work itself, the enthusiasm can be lost. One example might be that of a scientist who does not feel any admiration when contemplating what he/she is processing (not necessarily discovering) in his/her laboratory. He/She neither admires the results obtained, nor the methodology used, nor the daily laboratory routines ... He/She may have been a scientist in the past, but has become a technologist in the end; a maker of techniques; a person who does not question what he/she does or why he/she does it.

Another example could be that of a teacher whose sole objective is for the majority of his/her students to pass. He/She might dedicate all his/her efforts to 
that end. Furthermore, if he/she does not achieve such goal, because individual freedom of the student exists and each student can pass or not depending on his/her effort and not only on the worth of the teacher, he/she could lose the enthusiasm of seeing his/her students grow personally.

As the third cause of the lack of professional enjoyment, Marías points to the accumulation of materials and information. Certainly the excess of bureaucratization and information to be analyzed can divert the professional's attention from the essential, leading him/her more to the formalization of his/her profession than to the conceptual investigation or to answer the permanent questions related to his/her work, and as a consequence of all this, to the disappointment, even within the purest professional-personal vocation.

... se advierte muchas veces un elemento de despego o hasta de malhumor en los profesionales de las disciplinas más elevadas y en la docencia de ellas-una de las raíces de la crisis de esta última, y en particular de la Universidad. Creo que el origen de ello está en la falta de ilusión por estos menesteres. Cuando el trabajo es demasiado impersonal, cuando se realiza por acumulación de materiales e informaciones, cuando importa más el resultado y el éxito que la realización misma, la ilusión se desvanece, creo que eso afecta decisivamente a la calidad, pero más todavía a la personalidad de la obra, que resulta en muchos casos intercambiable, en lugar de estar ligada a la más profunda realidad del autor (Marías, 1990: p. 71). [Translated: ... An element of detachment or even moody is often noticed in professionals of the highest disciplines and in their teachingone of the roots of the crisis of the latter, and in particular of the University. I think the origin of it is in the lack of enthusiasm for these purposes. When the work is too impersonal, when it is done through the accumulation of materials and information, when the result and success matters more than its actual performance, the enthusiasm vanishes; I think that this decisively affects quality, but even more so the personality of the work, which is in many cases interchangeable, instead of being linked to the author's deepest reality].

Because of the lack of enthusiasm in the most vocational tasks, neither the professional product is the desirable one, diminished in its quality, as it was not made from a personal vocation; nor does the professional's self-grow as it might do. The professional task has not been personalized, as it was done in a generic way, reason why the person did not experience the enthusiasm, the joy of feeling that he/she carried out his/her work vocationally, involving himself/herself in it at a personal level.

\subsection{The Hierarchy of the Trajectories of Life}

Finally, in this brief chapter that we are analyzing, on enthusiasm and vocation, from the book Breve Tratado de la Ilusión (Short Treatise on Enthusiasm), Marías develops a point in which he emphasizes the hierarchy of life trajectories. He tells us that "el hombre va iniciando a lo largo de su vida diversas trayectorias" ["man begins various trajectories throughout his life"] (Marías, 1990: p. 
72); sometimes, we even start a new trajectory or vocational path when we are older, a fact that can even be criticized by some people when they see others do it. But Marías believes that it is absolutely normal, and even desirable, that we can start new trajectories at any time in life, although, certainly, such a moment, if it happens too late, could even condition the development of such vocational paths (Marías, 1990: p. 72).

There are people who, because they have passed of age, consider that they should not start new vocational paths. Such decision could cause an impoverishment of these people. There are times, on the contrary, that although new trajectories are not developed, the current ones can suffer a truncation, due to internal or external causes to the person. Alternatively, the same trajectory can undergo grafting at any age and produce new fruits (Marías, 1990: p. 73).

All this makes Marías consider a hierarchy of trajectories, although their external importance or their duration are not necessarily winning criteria. Sometimes a trajectory has been able to last for long years and has not even been identified by the subject; it was, therefore, an inert trajectory. Any trajectory can be frustrated, or hidden, marginal in its realization, or denied by the subject (Marías, 1990: pp. 73-74). All this will condition a state of disappointment in the subject, as the self lacks the necessary freedom to carry out a vocational career. That self will not develop into the ideal-self or destination; on the contrary, it will impoverish, causing that person a state of disappointment. Certainly, "if the link with the personal project is missing, there is no enthusiasm (Marías, 1990: p. 72)."

\subsection{Enthusiasm and Authenticity}

Pues bien, el criterio más seguro para medir la jerarquía vital, el grado de autenticidad de las diversas trayectorias, es el elemento de ilusión que las acompaña o falta en ellas. Cuando se considera una vida ajena, cuando se la estudia en sus huellas si se trata de una vida pretérita o lejana, o bien cuando se asiste a ella, se advierte la presencia o la ausencia, la vivacidad o apagamiento, de la ilusión en cada una de sus fases (Marías, 1990: p. 74). [Translated: The surest criterion to measure the vital hierarchy, the degree of authenticity of the various trajectories, is the element of enthusiasm that accompanies them or that is lacking in them. When you consider someone else's life, when you study it in its footsteps, if it is a past or distant life, or when you attend to it, you notice the presence or absence, the liveliness or fading, of the enthusiasm in each one of its phases].

This last quote is extremely interesting, associating the authenticity of the trajectories with the level of enthusiasm with which the person lives. A lack of enthusiasm is possibly associated with a lack of authenticity in my vocational career. According to Marías, enthusiasm is a diagnostic mark of personal authenticity, of the free pursuit of the randomly happened and necessarily accepted vocation.

And, on the contrary, disappointment speaks to us of interior pathology; per- 
sonal, intimate pathology of the heart, of freedom: something does not go well with the assumption of vocation; either I have not embraced the vocation at all, or I have not fully embraced it and I display a marginal path that leads me to disappointment, as such a path does not promote the growth of my own self.

Nada hace entender mejor lo que en cada momento es un hombre o una mujer que el mapa de sus ilusiones, con su verdadero relieve, con su intensidad, su carácter epidérmico o visceral, con la acumulación sobre cada una de ellas de más o menos dimensiones de esa biografía (Marías, 1990: pp. 74-75). [Translated: Nothing makes us better understand what a man or a woman is at any time than the map of their enthusiasm, with its true relief, with its intensity, its epidermal or visceral character, with the accumulation on each of them of more or less dimensions of that biography].

Therefore, we could better understand each person, their mood or lack of spirit, their actions, if we knew the map of their enthusiasm. Likewise, we can know ourselves better, since the state of personal enthusiasm presupposes authenticity of vocational response, even though it may be difficult to develop the trajectory that we are developing. The opposite, inauthenticity, consented to by external or internal elements of the subject, would be associated with lack of enthusiasm. Marías sets it out clearly in the following quote:

Pero no se piense sólo, ni primariamente, en el conocimiento de la vida ajena. ¿Hasta qué punto estamos en claro respecto a nosotros mismos? La consideración de lo que "debe ser", la imagen que los demás tienen de nosotros, la figura que nuestro contorno social nos impone, los cauces por los cuales discurre el torso de nuestra vida, lo que hemos sido-aunque acaso no lo seamos ya-, todo esto enturbia la claridad respecto a nosotros mismos, e introduce un elemento mayor o menor, en ocasiones gravísimo, de inautenticidad.

Lo que más puede descubrir a nuestros propios ojos quién somos verdaderamente, es decir, quién pretendemos ser últimamente, es el balance insobornable de nuestra ilusión. ¿En qué tenemos puestas nuestras ilusiones, y con qué fuerza? ¿Qué empresa o quehacer llena nuestra vida y nos hace sentir que por un momento somos nosotros mismos? ¿Qué presencia orienta nuestra expectativa, qué anticipación nos polariza, tensa el arco de nuestra proyección, se convierte en el blanco involuntario e irremediable de ella? (Marías, 1990: pp. 75-76).

[Translated: But do not think only, or primarily, about the knowledge of other people's lives. To what extent are we clear about ourselves? The consideration of what "should be", the image that others have of us, the figure that our social contour imposes on us, the channels through which the torso of our life runs, what we have been-although perhaps we are not now-, all this clouds the clarity regarding ourselves, and introduces a greater or lesser element, sometimes very serious, of inauthenticity.

What can discover more to our own eyes who we really are, that is, who we claim to be lately, is the unbearable balance of our enthusiasm. What do we have our enthusiasm on, and with what strength? Which task fills our lives and makes us feel that for a moment we are ourselves? What presence guides our expecta- 
tion, what anticipation polarizes us, tightens the arc of our projection, becomes its involuntary and irremediable target?].

\section{Enthusiasm and the Academic Vocation of University Professors}

The university professor is called to carry out two main activities: teaching and research. He/She is expected to perform a good job by being as excellent as possible in both fields. The scientific vocation is usually felt from an early age. To be trained as a scientist, a bachelor in science, in biomedicine, or in any of the life sciences is firstly chosen. Laboratory training, even extracurricularly, is usually followed as a personal decision, usually in summer time. Secondly, a master and a doctorate are carried out in a national or foreign university for four or five years. Thirdly, one or more postdoctoral stays,--varying in length from five to even ten years-are carried out, usually in different laboratories and even in different countries. Finally, after so many years, attempts are made by the trainee to start formally working as a science professional if the country in question allows it. In general, after completing a bachelor in science, it may even take 10 years for the scientist-in-training to be recognized as a scientist capable of leading and training others by directing doctoral theses, granting him/her a job in generally yet unstable conditions. The years of doctorate and post-doctorate are usually paid through training scholarships, so the job uncertainty in the scientific career is high.

If the workplace is a research center, the new scientist will face the request for scientific projects competitively awarded by national or international scientific research agencies, as long as he can demonstrate that he has a research group made up of a minimum number of qualified people who can carry out the requested project. It is then convenient to create a group by joining other scientists who share common interests. Much of the scientist's professional life will consist of requesting projects and winning them, to have the money for experimental work. This money is never guaranteed; the institution grants the workplace as such, as well as some general equipment, but not the financial means necessary to cover the day by day expenses of laboratory research projects. Curiously, it may happen that there is no money for research, while there is money to keep the scientist in his/her job.

Usually, the biggest problem is the hiring of personnel associated with the project, since each project is usually led by a scientist and is undertaken or experimentally carried out by a small number of predoctoral fellows. Scholars' salaries are normally covered by training scholarships. But the scholarships are requested competitively by the fellows with the endorsement of the scientist or director. If a scholarship is not obtained, the doctoral student cannot carry out the doctoral thesis in that research group.

The scientist who, after his/her pre and postdoctoral stays, is recruited by a university faces an added problem: he/she has to teach and combine teaching 
with scientific activity. Some universities, rather few, recruit scientists with exclusive dedication to research. They are even appointed academic professors. But most universities obviously want to attract figures who dedicate to teaching, although it is true that they increasingly prefer these figures to be recognized scientific researchers. The problem is that researchers at university have to do two activities that take a long time each: teaching and research.

Certainly the latter is much more complex in its possibility of realization since it depends on the scientist being able to get money to carry out the experiments, as well as on the personnel assigned to his/her project, usually predoctoral fellows who will not be financed by the university, but through competitive scholarships. Then, fellows are a scarce staff that will only be able to work on the project for 3 or 4 years, the duration period of most scholarships. Scientists dedicate a large part of their efforts to achieve these aims (financial and personnel attached to the project). Another enormous part consists in the development of the research project as such, its direction, planning, updating, interpretation of results, writing and publication of scientific articles in prestigious international journals, communications to congresses...

Also, teaching to undergraduate and master students is something required to the scientist if working at a university. Teaching requires exhaustive preparation of the classes that make up a course, as well as attention to students in their personal advice. In addition, currently the teacher-student interaction is not reduced to the master class, but the teacher is in contact with the student by telematic means almost constantly, at the level of emails, and through multiple activities that the student has to carry out and the teacher correct, as teaching has evolved towards a continuous assessment system in recent years.

There is a great accumulation of realities that make the work of the university researcher and professor so difficult. It is not the inherent difficulty of his/her job that diminishes enthusiasm, since normally the university professor is used to suffering, to the scarcity of means, and to the struggle to improve curricula. But there may be causes that hurt more strongly and make the vocation sick, after a decrease in enthusiasm. Among them, I highlight the shortage of research personnel. It is not desirable for a scientist to grow old and always have, at most, one young intern to help him. If the professor is a good researcher, he must be cared for by his own university, providing him/her with personnel directly assigned to his/her research group -otherwise there will not even be a group-. The accumulation of bureaucratic tasks to the detriment of thinking is also very painful for a vocational professor-scientist. The lack of time necessary to admire, to rest the knowledge, to give it a new explanatory form, to rethink it and to write it in articles or books, will lead to a decrease in enthusiasm and the possible abandonment of the creative task.

\section{Conclusion}

Julián Marías makes us see the importance of vocation in personal development, 
in the growth of one's being. There are important elements in the field of vocation, such as circumstance, chance and trajectories. The circumstance is imposed on me, while the vocation is proposed to me. Moreover, I have the moral obligation to respond to the proposed vocation, taking into account my particular circumstance. However, the path to vocation is made through paths of different intensity and life span. The enthusiasm consists of anticipating the desire to achieve our vocation. In this way, an enthusiastic person brings the future to himself/ herself, anticipates it. It is not good to hold on to an idea of a unique vocation, without which nothing makes sense; the vocation must be able to be reached; something that cannot be done would not be real. For reaching the vocation we count with enthusiasm as anticipation of the joy of the vocation (Marías, 2015). Enthusiasm gives us the possibility to continue on the path towards our vocation. Not only oneself can stop the full development of the vocation, but also factors which are external to the person. All this forces us to think seriously about how to take care of our vocational path, and of our level of enthusiasm maintained over time. It will also be important to pay proper attention to chance and try to respond to it, to be able to modify our trajectories, but always aiming to carry them out within our vocational path.

In this way, trying to resolve the question that concerns us about university professors who dedicate themselves to research and teaching, I believe that those who feel that they have lost their research vocation could be wrong. There may have been multiple factors, already analyzed, that make it difficult to feel the enthusiasm for the investigation; and it is possible that even the vocational scientist continues to investigate without enthusiasm. But, even if you stopped investigating, you should not feel that you have not developed your vocation; rather, you have completed one of your trajectories (the researcher), but it is very possible that you will be able to open another trajectory (the teacher), both within the same and unique vocation that we could call theoretical, academic, investigative vocation, vocation to knowledge, to conceptualization, to scientific analysis. If a vocational scientist leaves scientific research, he/she does not stop being a scientist. The vocation does not die. There are trajectories of it that develop at different times. Therefore, it is necessary to recognize the vocation, be faithful to it, follow it as far as possible without falling into mania, closure, taking into account the variable condition of reality and that life does not end in any of its parts (Marías, 1995).

\section{Acknowledgements}

The author thanks J.I. Galparsoro, J.I. Murillo and L.M. Gaitán, for comments and advice.

\section{Funding}

Financial support for this work was provided by a grant from the Fundación Universidad de Navarra, Pamplona, Spain. 


\section{Conflicts of Interest}

The author declares no conflict of interest.

\section{References}

Cambridge Dictionary (2020). Cambridge: Cambridge University Press. https://dictionary.cambridge.org/dictionary/english/illusion

Diccionario de la Lengua Española (2019). Madrid: Real Academia Española. (In Spanish) https://dle.rae.es/ilusi\%C3\%B3n

Marías, J. (1990). Breve tratado de la ilusión. Madrid: Alianza Editorial. (In Spanish)

Marías, J. (1995). La vocación. (In Spanish)

https://www.youtube.com/watch?reload $=9 \& \mathrm{v}=-9 \mathrm{xGSosIG7Y}$

Marías, J. (2015). La ilusión. (In Spanish)

https://www.youtube.com/watch?v=bd7vB4seozY 